\title{
ANALYSIS OF CLIMATE VARIABILITY AND ITS RELATIONS TO VEGETATION DYNAMICS IN TOGO, WESTERN AFRICA FROM 1984 TO 2017
}

\author{
FANDJINOU, K. ${ }^{1,2}-$ ZHANG, K. B. $.^{{ }^{*}}-$ FOLEGA, F. $^{2}-$ MUKETE, ${ }^{3}{ }^{3}-$ YANG, X. H. ${ }^{4 *}$ \\ WALA, $\mathrm{K}^{2}{ }^{2}-$ AKPAGANA, $\mathrm{K}^{2}$ \\ ${ }^{1}$ School of Soil and Water Conservation, Beijing Forestry University, 35 Qinghua East Road, \\ Haidian District, Beijing 100083, China \\ (e-mail:fandnew@yahoo.fr-F.K., ctccd@126.com-Z.K.B) \\ ${ }^{2}$ Laboratoire de Botanique et d'Ecologie Végétale, Université de Lome, BP 1515, Lome, Togo \\ (e-mail: ffolegamez@live.fr-F.F., kpwala@yahoo.fr-W.K., koffi2100@gmail.com-A.K.) \\ ${ }^{3}$ Department of Forest Management, Beijing Forestry University, 35 Qinghua East Road, \\ Haidian District, 100083 Beijing, China \\ (e-mail: munasawa@gmail.com-M.B) \\ ${ }^{4}$ Institute of Desertification Studies, Chinese Academy of Forestry, P. O. Box 35, Yiheyuanhou, \\ Haidian District, Beijing 100091, China \\ (e-mail: yangxh@caf.ac.cn-Y.X) \\ *Corresponding authors \\ e-mail: ctccd@126.com, yangxh@caf.ac.cn \\ (Received $8^{\text {th }}$ Feb 2019 ; accepted $29^{\text {th }}$ Mar 2019)
}

\begin{abstract}
Vegetation, climate and anthropogenic factors in the country of Togo are thought to mutually correlate, however, the degrees to which they correlate remains unclear. This study examined and analyzed patterns of climate variability and how these patterns have influenced vegetation cover dynamics in Togo. Based on data collected from eight meteorological stations, the global climate monitor and European Space Agency, this study analyzed existing trends and relationships between vegetation cover, climate and Normalized Difference Vegetation Index (NDVI) using Mann Kendall non-parametric test, ANOVA and p-value tests. The results showed that (1) rainfall correlated strongly with NDVI (pvalue $<0.00001)$, (2) evapotranspiration was influenced by annual temperatures in the eight sampled meteorological stations across the country (p-values $<0.0001$ ), (3) evapotranspiration and rainfall were negatively correlated, (4) annual NDVI changes can be used to monitor annual rainfalls, (5) Anthropogenic disturbances, such as deforestation from uncontrolled tree logging, farming and low household income, can be quoted among the limiting factors of vegetation cover.
\end{abstract}

Keywords: greenness drivers, remote sensing, NDVI, sustainable forest management, plant seasonality

\section{Introduction}

From 1990 to 2015, the total forest coverage in Togo decreased from 12.59 to $3.46 \%$ showing a loss of $9.13 \%$ as estimated by the United Nations Food and Agricultural Organization. Studies have shown many significant interchanges occurring between climate, vegetation and human activities, for example, interactions have been found between the soil and atmosphere (Zhang et al., 2011), and vegetation is thought to respond to climate changes through temperature and rainfall variations, and obviously or subtly by seasonal changes (Weiss et al., 2004.; Cui and Shi, 2010.; Meng et al., 2011). 
Various studies have analyzed vegetation indices to understand the impacts of climate on vegetation cover, showing that rainfall regimes correlate strongly with Normalized Difference Vegetation Index (NDVI) (Martiny et al., 2006; Capodici et al., 2008), green biomass estimation (Rosental et al., 1985; Prince et al., 1991; Julien, 2014) and as vegetation photosynthetic activity indicator (Gausman et al., 1985; Gilabert et al., 1985). Even early satellite data from the 1970's were used to monitor vegetation and climate patterns conditions for management purposes (Rouse et al., 1974). Some research findings showed that an increase of temperature could potentially change the ecosystem composition of the vegetation cover (Serreze et al., 2000). Other studies have shown broad results that NDVI and rainfall correlated effectively (Kendall et al., 1975; Nicholson et al., 1994; Richard et al., 1998; Foody et al., 2003; Ma et al., 2006). For instance, the influence of temperature on NDVI was significant only during the early and the late growing season, while NDVI correlated with rainfall within the growing season (Wang et al., 2012). However, NDVI time series were not strongly correlated with climate variations at global scale, even if rainfall was reported to have the capacity to limit vegetation growth in semi-arid areas (Schultz, 1995; Ichii et al., 2002).

\section{Literature review}

Dominated by the Sahel's arid and semi-arid climatic conditions, West Africa reported obvious climatic changes by the early and late drought period (1970 and 1980), shown by decadal increases of the temperature and a decrease of rainfall (Biasutti et al., 2009). These findings have been consistent in Togo, with climate changes being assessed through slight increases of temperature and irregular rainfall regimes (Adjoussi, et al., 2000). Climate change in the area is also projected to continue exacerbating weather and climate conditions the future decades (IPCC, 2013).

Moreover, many other studies addressing climate change showed that in West Africa, and especially in Togo, temperatures have been increasing steadily each year from 0.4 to $1.6^{\circ} \mathrm{C}$, depending on the ecoregions in Togo (Badameli et al., 2015). Estimates of green vegetation dynamics in West Africa, especially in the North mountainous region of Togo, have revealed that since 1987 vegetation has been declining, and socioeconomic factors were thought to be the main dynamic factors of this decrease (FAO, 2017). Togo was quoted as having some of the highest deforestation rates in the world, with a deforestation rate of $4.5 \%$ from 2002 to 2005 and $5.75 \%$ from 2005 to 2010 (FAO, 2006; Biasutti et al., 2009). These deforestation rates are due to supplying firewood as main source of energy for $90 \%$ of the household energy needs (Fontodji et al., 2007; Gazull et al., 2009; Koku et al., 2009). Other factors for vegetation degradation include agricultural pressure, animal husbandry and bush fires (Traore et al., 1998)

Within the past decades, most of the studies related to vegetation in Togo were analyzed at the local level for vegetation management strategies or plant species inventory. This is the first study to explore climatic variations and the drivers between climate variations and vegetation at two scales from local to national level. The current study bridge gaps in the research about Togo by putting together climate and vegetation variations using NDVI, temperature, rainfall and potential evapotranspiration (PET) data to clarify the relationship of vegetation and climate changes under a tropical climate conditions. 


\section{Materials and methods}

\section{Study area}

Togo $\left(6^{\circ} 06^{\prime} \mathrm{N} ; 11^{\circ} 08^{\prime} \mathrm{N} ; 0^{\circ} 09^{\prime} \mathrm{W}\right.$ and $\left.1^{\circ} 49^{\prime} \mathrm{W}\right)$, a West African country, covers a total area of $56,600 \mathrm{~km}^{2}$ and is bordered by the Atlantic Ocean, Benin, Ghana, and Burkina-Fasso to the South, East, West and North respectively. With $61 \%$ urban population and 229 persons $/ \mathrm{km}^{2}$ of density, his total population was 7,965,055 persons in 2017 according to the United Nation for Food and Agriculture Organization (FAO). This population has quadrupled from 1960 to 2010, since gaining independence, with $60 \%$ under the age of 25 years. Togo's tropical climate is characterised by two main regimes from the south to the north. The Guinean regime comprises two rainy seasons and two dry seasons with an annual rainfall from 1000 to $1600 \mathrm{~mm}$ while the Sudanese regime in the North has only one short rainy season and one long dry season with an annual rainfall of $850-1400 \mathrm{~mm}$ (Badameli et al., 2015) and an annual average temperature around $27.8^{\circ} \mathrm{C}$. The country has rich vegetation with more than 4000 plant species, mainly from the forest species as discovered recently (Brunei et al., 1984; Akpagana et al., 1994; Kouami et al., 2009). Unfortunately, this rich flora is threatened by anthropogenic activities which depend on forest resources for fire wood energy and charcoal (Folega et al., 2011). The soils of Togo are diverse and include ferralitic soils, vertisols, tropical ferruginous soils, although mainly dominated by poorly developed soils (Folega et al., 2015). The hydrology of Togo comprises three southern rivers including Mono $(450 \mathrm{~km})$ the longest, Zio $(176 \mathrm{~km})$ Haho $(140 \mathrm{~km})$ and lagoons, Togoville, Lomé and Aneho lagoons. In the northern part the Oti basin, there is the only one river watering the vegetations. The climate of Togo is under the influence of two high-pressure air masses, Harmattan and Monsoon, whose encounter produces an InterTropical Front (FIT) that determines the seasons by its fluctuation. In terms of botany, Togo comprises five ecofloristic areas (Ern et al., 1979; Kokou et al., 2009) which combine ecological, floristic and physiognomic patterns, including Sudanese savannas in the northern plains, dry savannahs and forests covering the northern mountains, Guinean woodland savannahs in the central plains, dense semi-deciduous forests in the southern section in the Mont's of Togo, and mosaics (savannahs, forest relics and fallow forests) in the coastal plains of southern Togo. Land use cover is estimated at $67.4 \%$ of agricultural land, $45.2 \%$ of arable land, $3.8 \%$ of permanent crops, $18.4 \%$ of permanent pasture and of forest $4.9 \%$ others estimates to $27.7 \%$ in 2011.

\section{Data collection}

\section{Meteorological data and NDVI}

Data were downloaded from eight meteorological stations located in various ecofloristic regions of the country (Fig. 1). The meteorological stations are found in open air environments free from shade. These meteorological stations include Lomé

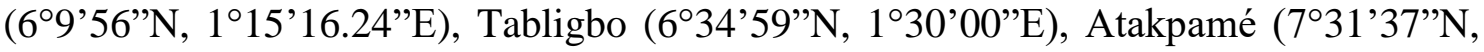
$\left.1^{\circ} 7^{\prime} 36^{\prime \prime} \mathrm{E}\right)$, Kouma konda $\left(6^{\circ} 95^{\prime} \mathrm{N}, 0^{\circ} 58^{\prime} \mathrm{E}\right)$, Mango $\left(10.37^{\circ} \mathrm{N} / 0.47^{\circ} \mathrm{E}\right.$, $)$ Sokodé $\left(8.98^{\circ} \mathrm{N} / 1.15^{\circ} \mathrm{E}\right)$, Kara $\left(9.55^{\circ} \mathrm{N} / 1.17^{\circ} \mathrm{E}\right)$, Dapaong $\left(10.87^{\circ} \mathrm{N} / 0.25^{\circ} \mathrm{E}\right)$ from 1984 to 2017. The NDVI annual time series data were available from the European Space agency at the resolution of $500 \mathrm{~m}$ completed from the MODIS website for the years 1992 and 1993 at the same resolution. The annual evapotranspiration data were freely available in the global climate monitoring website. The Normalized Difference Vegetation Index 
(NDVI) ranged from (-)1 to (+)1. It can be extremely negative for water surfaces, zero for barren areas or rocks, sands or snow and highly positive for healthy vegetation including grassland, shrub land, temperate and tropical rainforest (Tucker et al., 1979; Tarpley et al., 1984; Gausman et al., 1985; Goward et al., 1985; Rosental., 1985; Sellers et al., 1985; Townshend et al., 1985; Bartlett et al., 1988; Wilson et al., 2002).

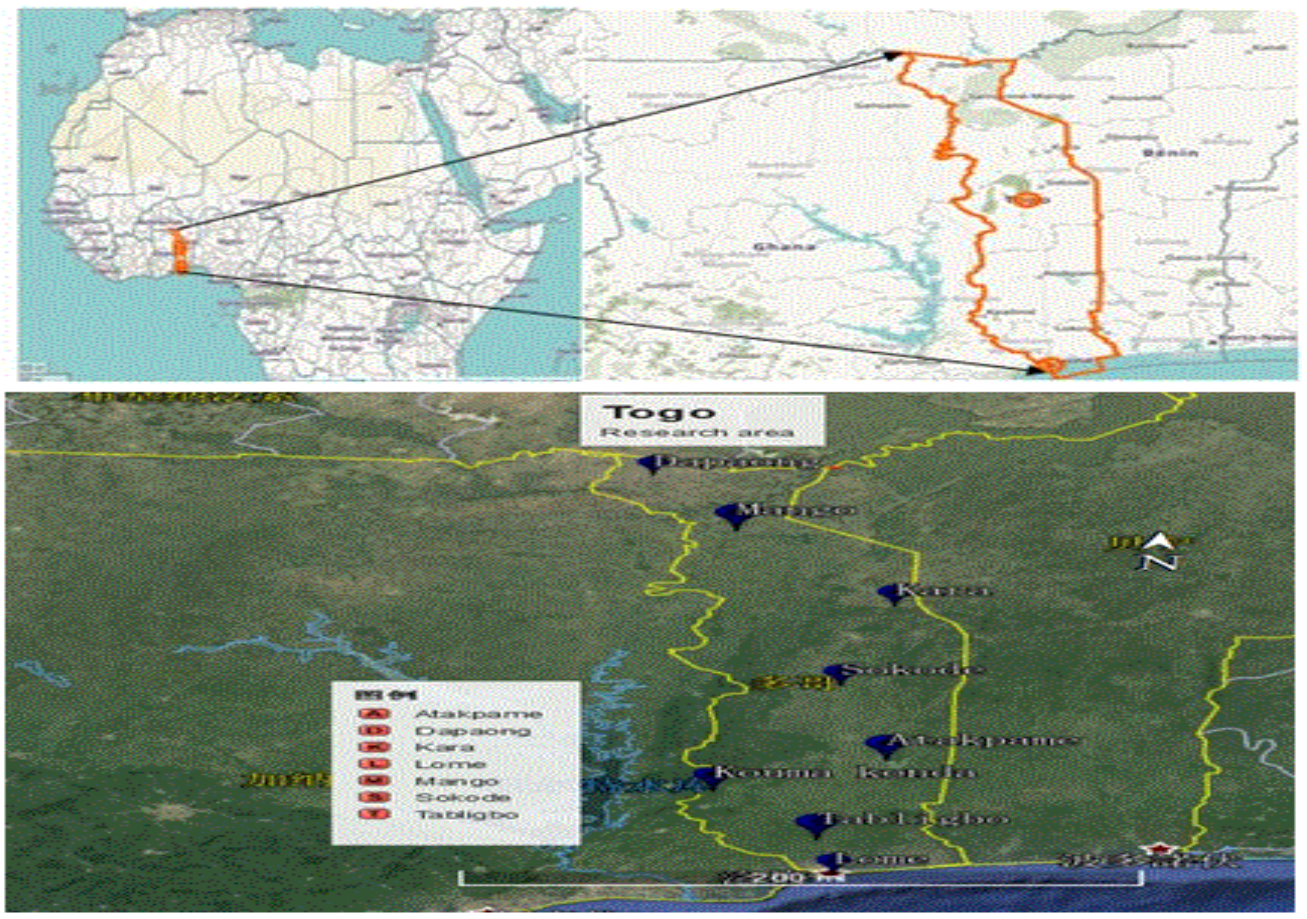

Figure 1. Location map of the study area

\section{Statistical analyses}

\section{Regression analysis}

All collected data were analyzed by regression (Eq. I) method with SPSS software to determine the relationship between dependent and independent variables. Thus, the dependent variables were regressed on the independents in order to determine if their relation was significant and how much the confidence of the dependents explain the independents. The p-value $<0.05$ represents statistically a significant relationship to 95\% of confidence interval (Kleinbaum et al., 1998; Mbatu et al., 2006; Mukete et al., 2018).

$$
y=a x+b
$$

where $\mathrm{y}$ is the dependent variable and $\mathrm{x}$ the independent variable.

\section{Non parametric test of Mann Kendall (MK)}

Non-parametric analysis known as Mann Kendall (MK) was performed using the following steps: the observed data in year $Y_{j}$ and $Y_{i}$ respectively differ and the sign $\left(Y_{j}\right.$ $\mathrm{Y}_{\mathrm{i}}$ ) equals to $1,-1$ or 0 with $\mathrm{j}>\mathrm{i}$. The test statistic, $\mathrm{S}$, was then calculated (Eq. 2). 


$$
S=\sum_{i=1}^{n-1} \sum_{j=i+1}^{n} \operatorname{Sign}\left(y_{j}-\mathrm{y}_{\mathrm{i}}\right)
$$

When $\mathrm{S}$ is a larger positive integer, the values measured later tend to be larger than earlier values and an upward trend is indicated. When $S$ is a larger negative number, later values tend to be smaller than earlier values and a downward trend is indicated. When the absolute value of $\mathrm{S}$ is small, no trend is indicated. The test static $\tau$ was calculated (Eq. 3).

$$
\tau=\frac{S}{n(n-1) / 2}
$$

$\tau$ has a range from -1 to +1 and is analogous to the correlation coefficient in regression analysis. The null hypothesis of no trend is rejected when $\mathbf{S}$ and $\tau$ are significantly different from zero. If a significant trend is found, the rate of change can be calculated using the Sen slope estimator (Eq. 4).

$$
\beta=\operatorname{median}\left(\frac{y_{j}-y_{i}}{x_{j}-x_{i}}\right)
$$

For all $\mathrm{i}<\mathrm{j}$ and $\mathrm{I}=1,2, \ldots, \mathrm{n}-1$ and $\mathrm{j}=2,3, \ldots \mathrm{n}$; in order words, computing the slope for all pairs of data that were used to compute $\mathrm{S}$. The median of those slopes is the Sen slope estimator. For Mann et al. (1945), the S statistic is roughly in the norms if and only if the time interval is greater than eight. When there is no tie between the values of the data, see Equations 5 and 6.

$$
\begin{gathered}
E(s)=0 \\
\operatorname{Var}(S)=\frac{n(n-)(2 n+5)}{18}=\sigma
\end{gathered}
$$

The standard test statistic $\mathrm{Z}$ is calculated by the following formula:

$$
\begin{aligned}
& Z=\frac{S-1}{\sqrt{\operatorname{Var}(s)}} \operatorname{For} S \geq 0 \\
& Z=0 F o r S=0 \\
& Z=\frac{S+1}{\sqrt{\operatorname{Var}(s)}} \operatorname{For} S \leq 0
\end{aligned}
$$

When there is no trend or a null hypothesis, $\mathrm{Z}$ evolves with mean zero. A positive $\mathrm{Z}$ value indicates an upward trend value while a negative value indicates a downward trend. The p-value of a Mann-Kendall $\mathrm{S}$ can then be determined using the normal cumulative distribution function (Eq. 8; Blain, 2013; Helsel et al., 1992).

$$
p=2[1-\phi(\mid z) \mid]
$$


where $\Phi(p)$ describes the cumulative distribution function of a standard normal variate.

\section{Results}

\section{Climate variability and vegetation dynamics}

The NDVI analysis showed variations in vegetation cover throughout the country, (Fig. 2), and correlation analysis performed also showed climatic factors to correlate with NDVI, (Figs. 9-10). Observing the correlation between NDVI and temperature at the national level.

\section{NDVI, temperature, rainfall and evapotranspiration changes at local level}

The annual time series of temperature, rainfall, evapotranspiration and NDVI in Togo at national level from 1984 to 2017 (Fig. 2), shows obvious changes in each parameter during these three last decades in Togo. Temperatures is increasing continuously especially from 1990 in the country. The NDVI and mean rainfall are changing in the same way so that an uptrend year of rainfall corresponds to an uptrend year of NDVI. The temperature and the evapotranspiration both changed at certain time period in the opposite directions especially from 1990 till 2017.

From the analysis we can conclude NDVI and rainfall correlate strongly and positively, similarly with mean annual temperature and evapotranspiration, while the annual rainfall and evapotranspiration correlate negatively (Fig. 3). It can be seen also that, there is no correlation between mean NDVI and mean annual temperature under the tropical climate condition that prevails in the research area.

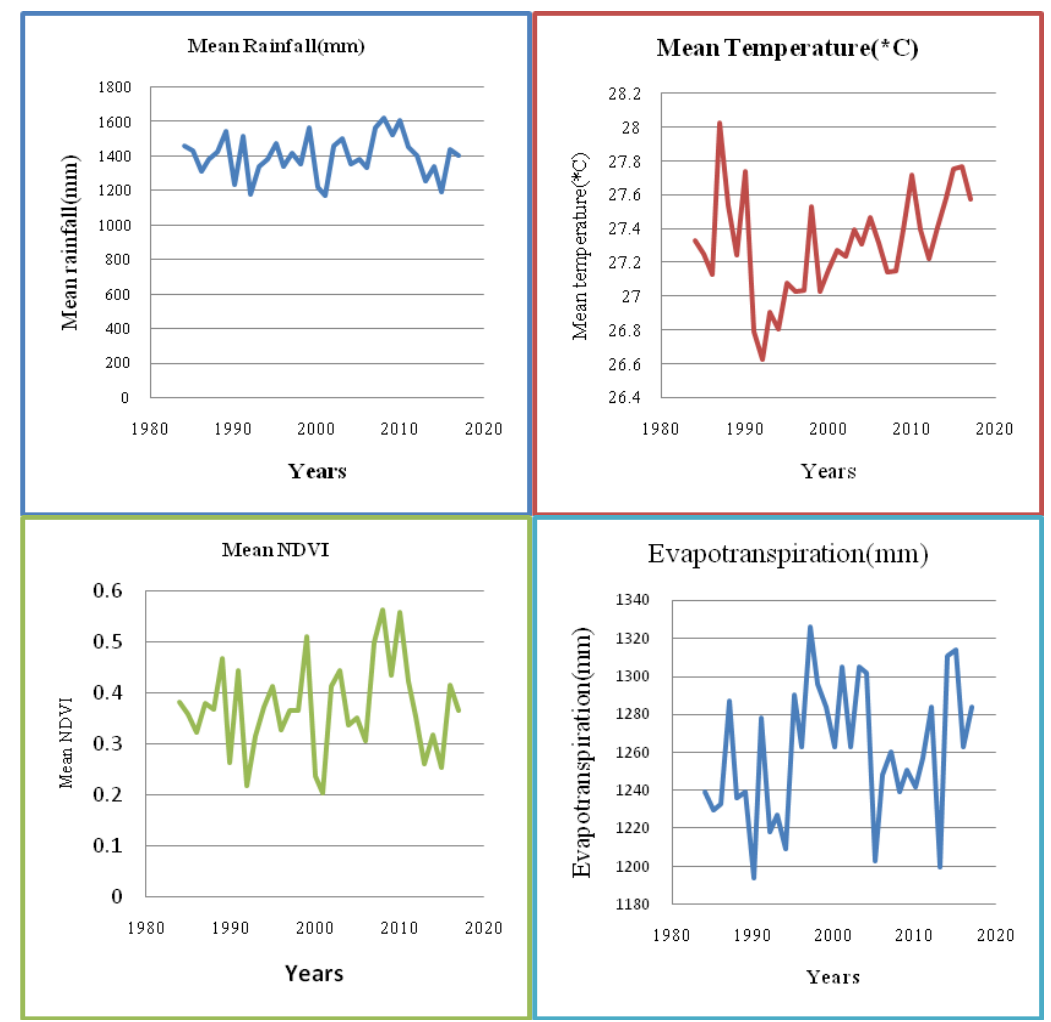

Figure 2. Annual time series changes of mean NDVI, rainfall ( $\mathrm{mm}$ ), evapotranspiration ( $\mathrm{mm}$ ) and temperature $\left({ }^{\circ} \mathrm{C}\right)$ at national scale in Togo during 1984-2017 


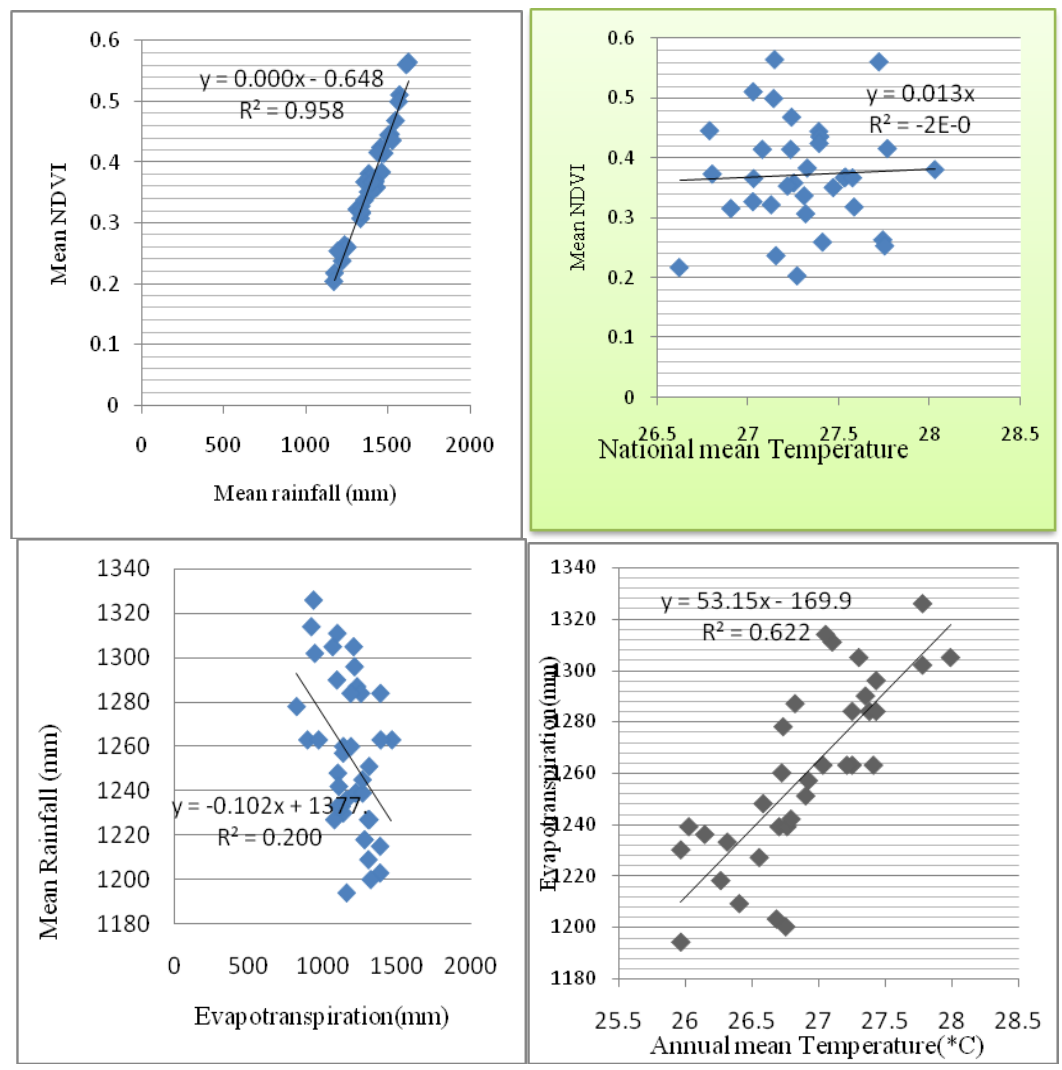

Figure 3. Cross-analysis relationship between mean NDVI, evapotranspiration, temperature $\left({ }^{\circ} \mathrm{C}\right)$, rainfall at national scale in Togo from 1984 to 2017

\section{National level forest area changes in Togo from FAO survey (Fig. 4)}

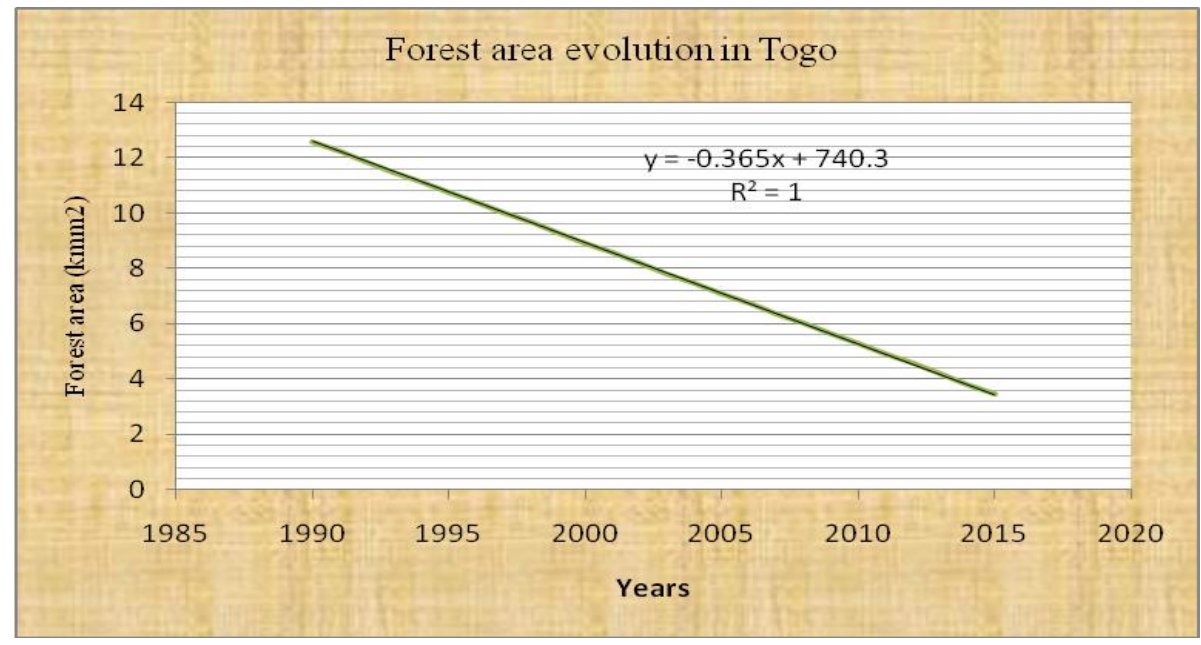

Figure 4. Togolese forest area changes from 1990

\section{Local scale climate variability and vegetation dynamics}

The relationship between climate variability and vegetation cover was performed at local scale for all the eight sampled meteorological stations (Figs. 5-10). 


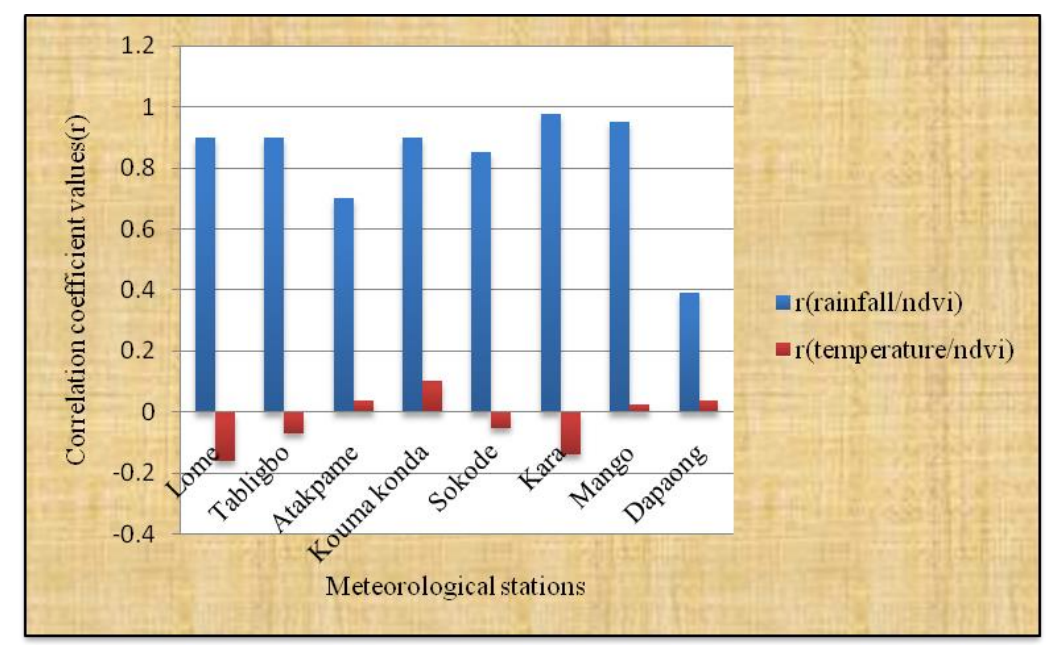

Figure 5. Correlation coefficient analysis between NDVI/ rainfall and NDVI/temperature for the entire study area in the eight meteorological stations from the South subtropical Guinean climate to the North tropical Sudanese climate during the 33 years of observation

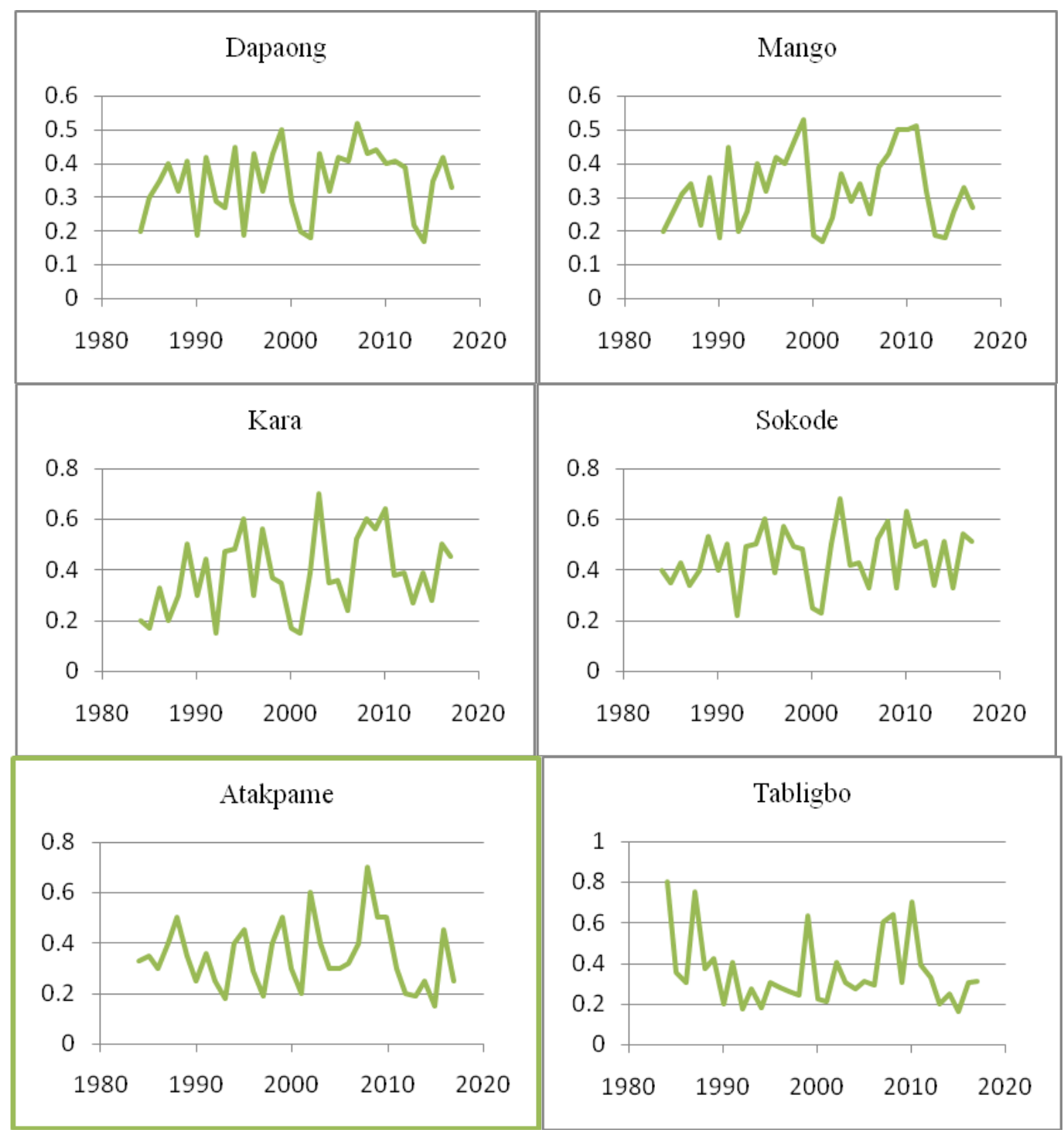




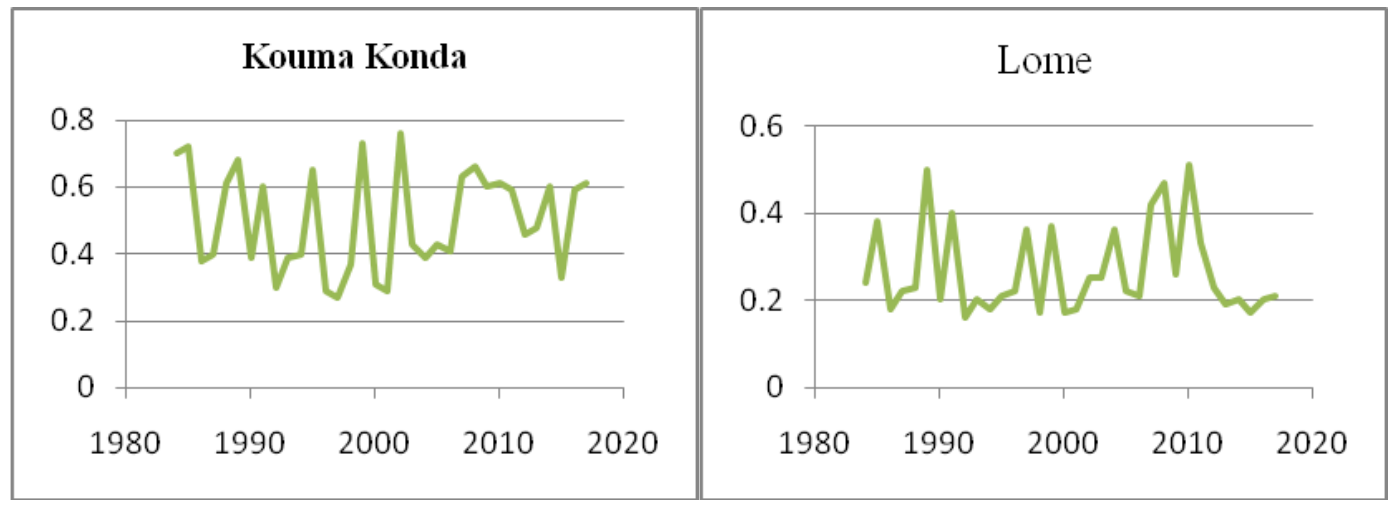

Figure 6. Annual changes in NDVI for the eight sampled meteorological stations in Togo during 1984-2017
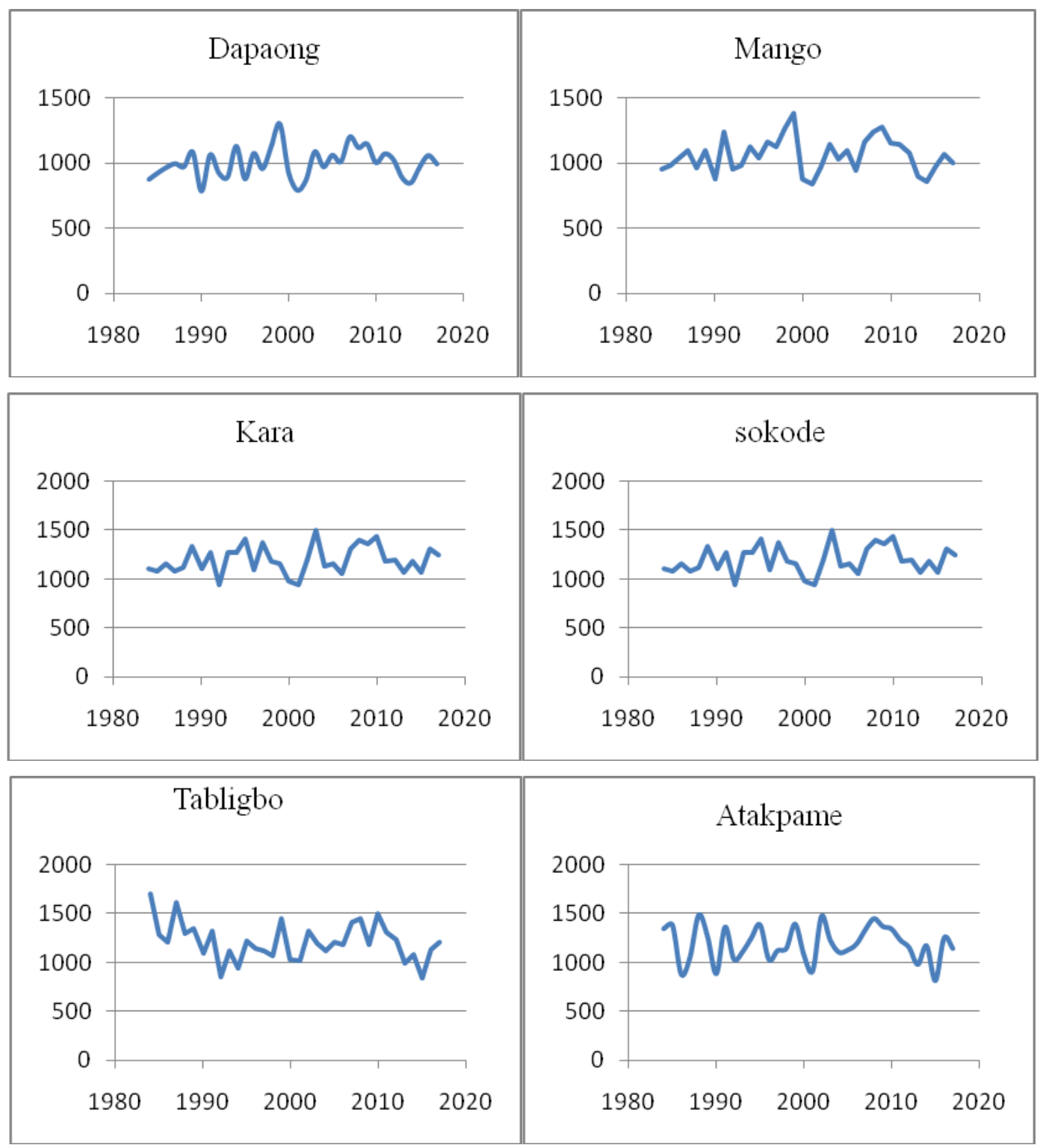


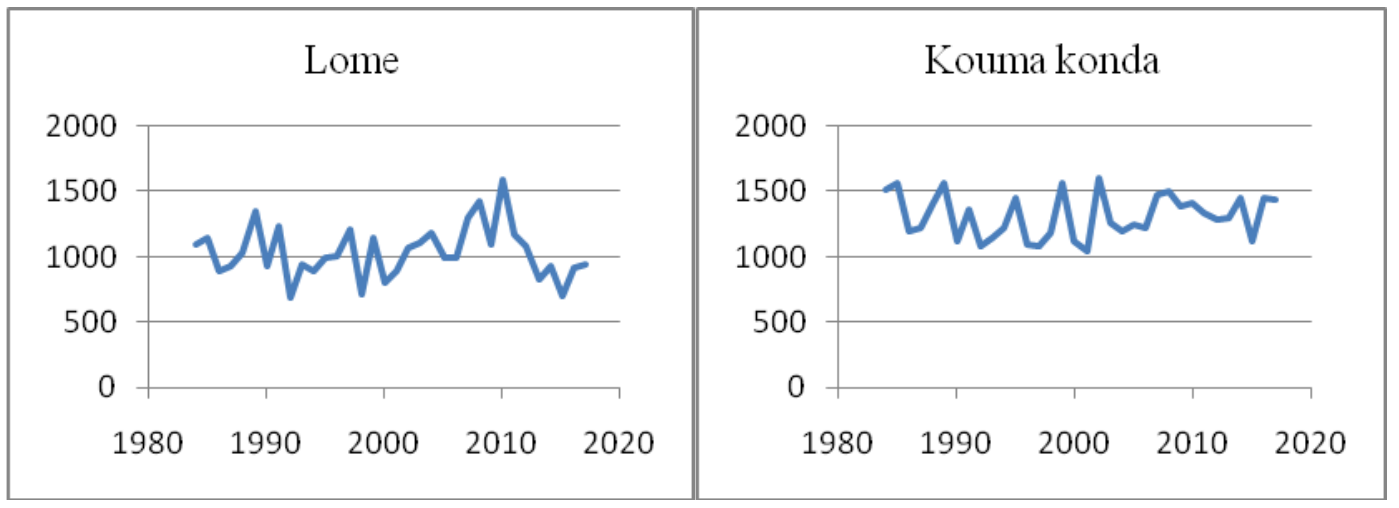

Figure 7. Annual of rainfall ( $\mathrm{mm}$ ) in the eight sampled meteorological stations in Togo during 1984-2017
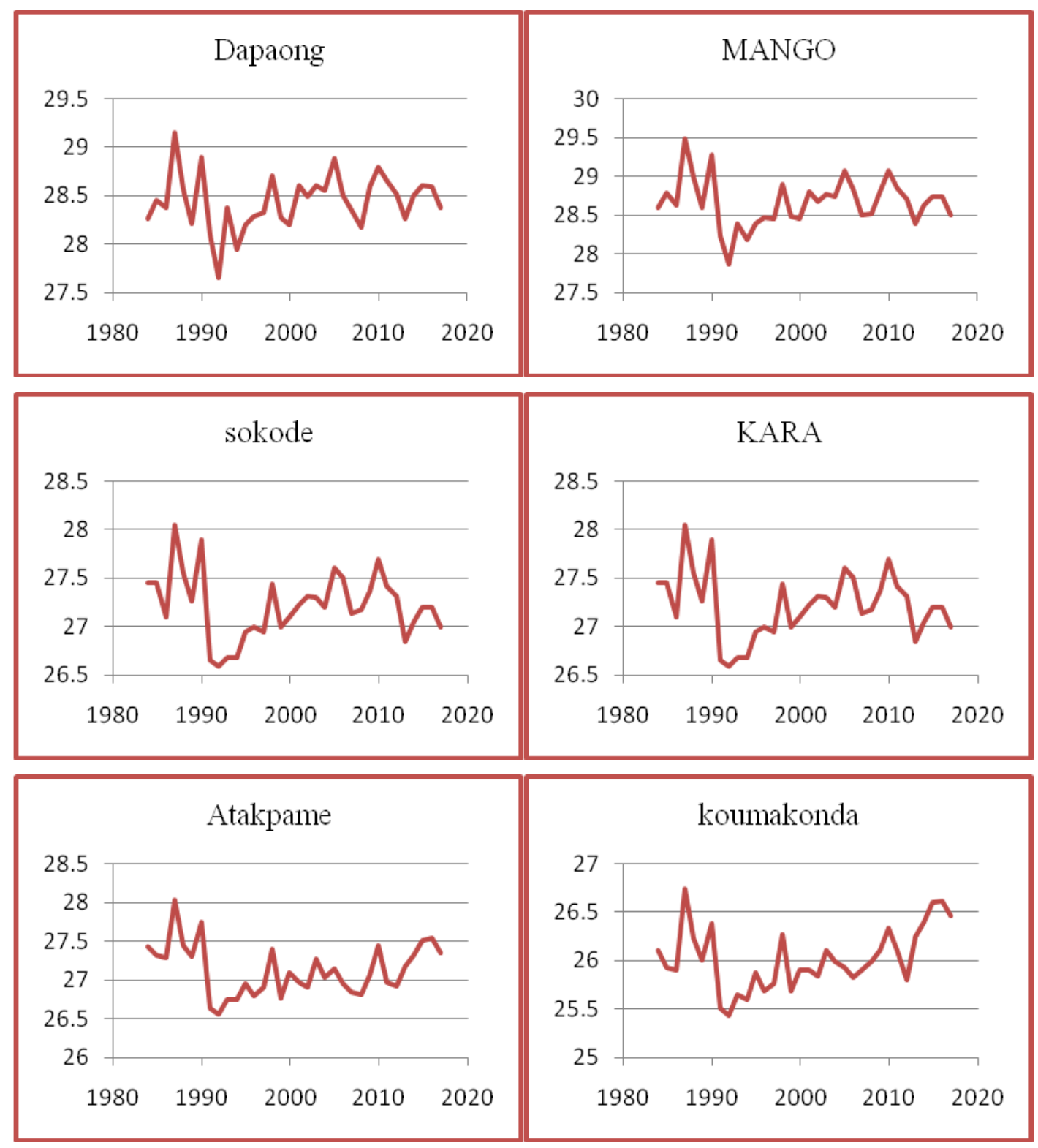


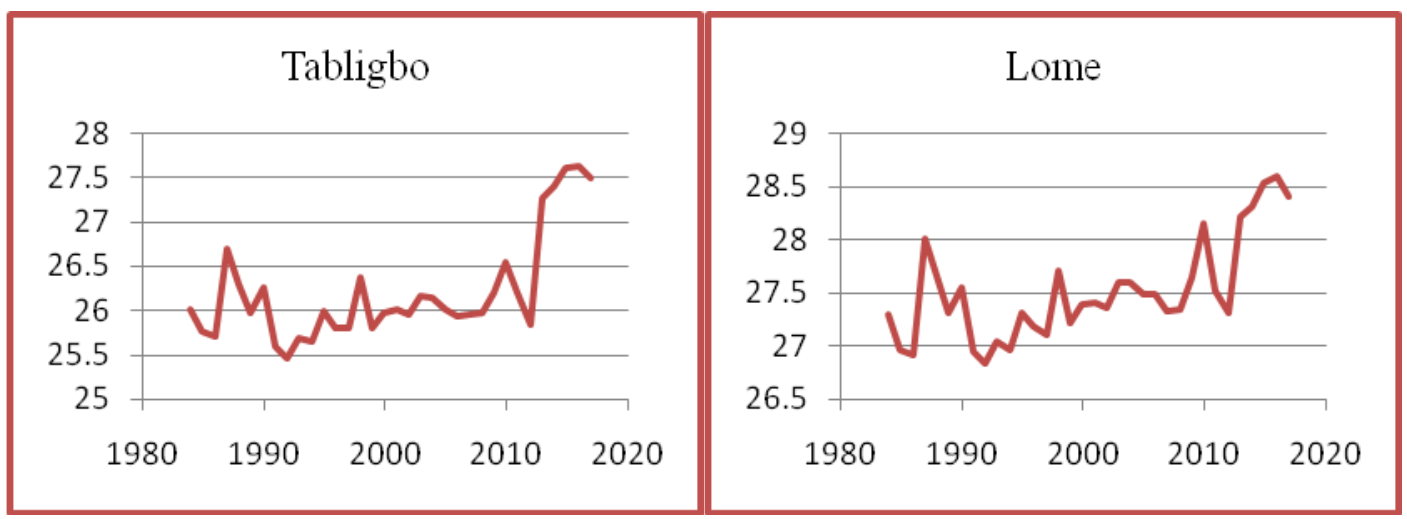

Figure 8. Time series of annual temperature $\left({ }^{\circ} \mathrm{C}\right)$ variations in eight meteorological stations

\section{Regression analysis at local level}
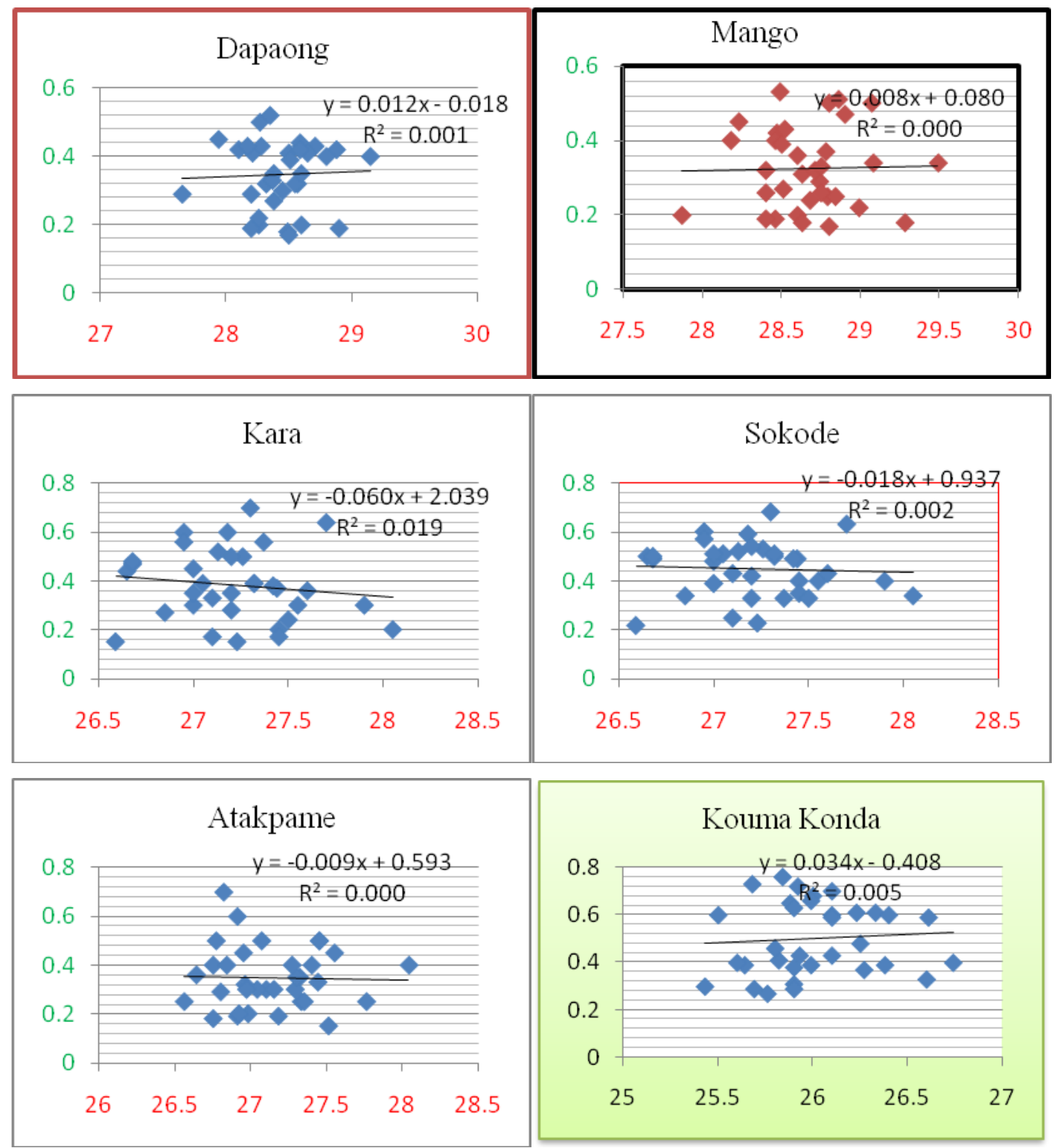

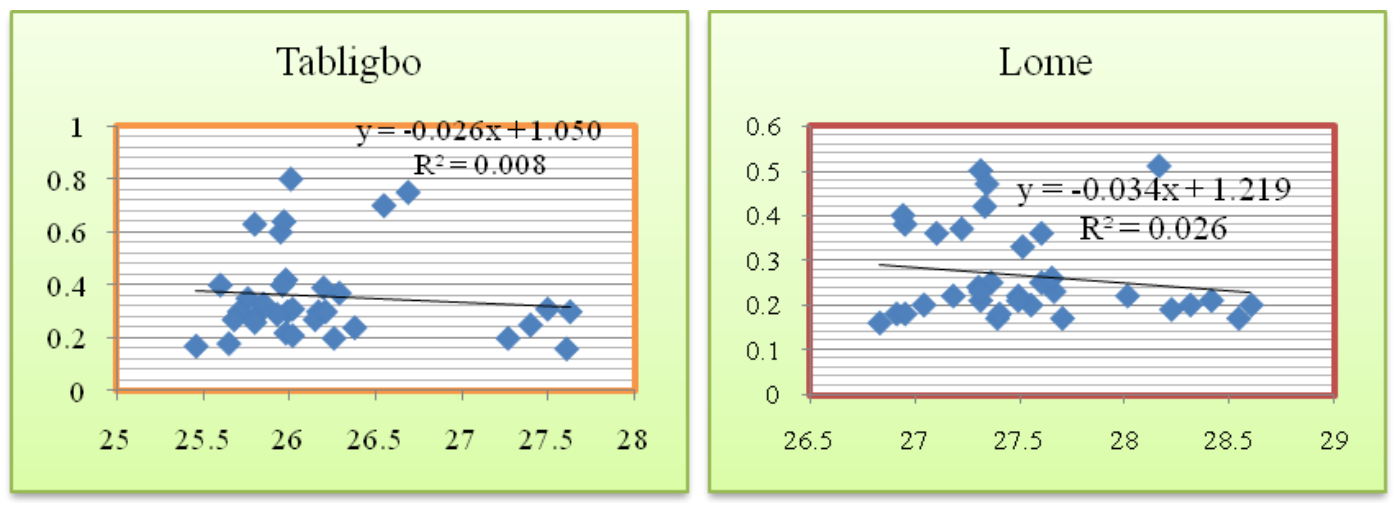

Figure 9. Annual changes in NDVI, temperature $\left({ }^{\circ} \mathrm{C}\right)$ for the eight sampled meteorological stations in Togo during 1984-2017
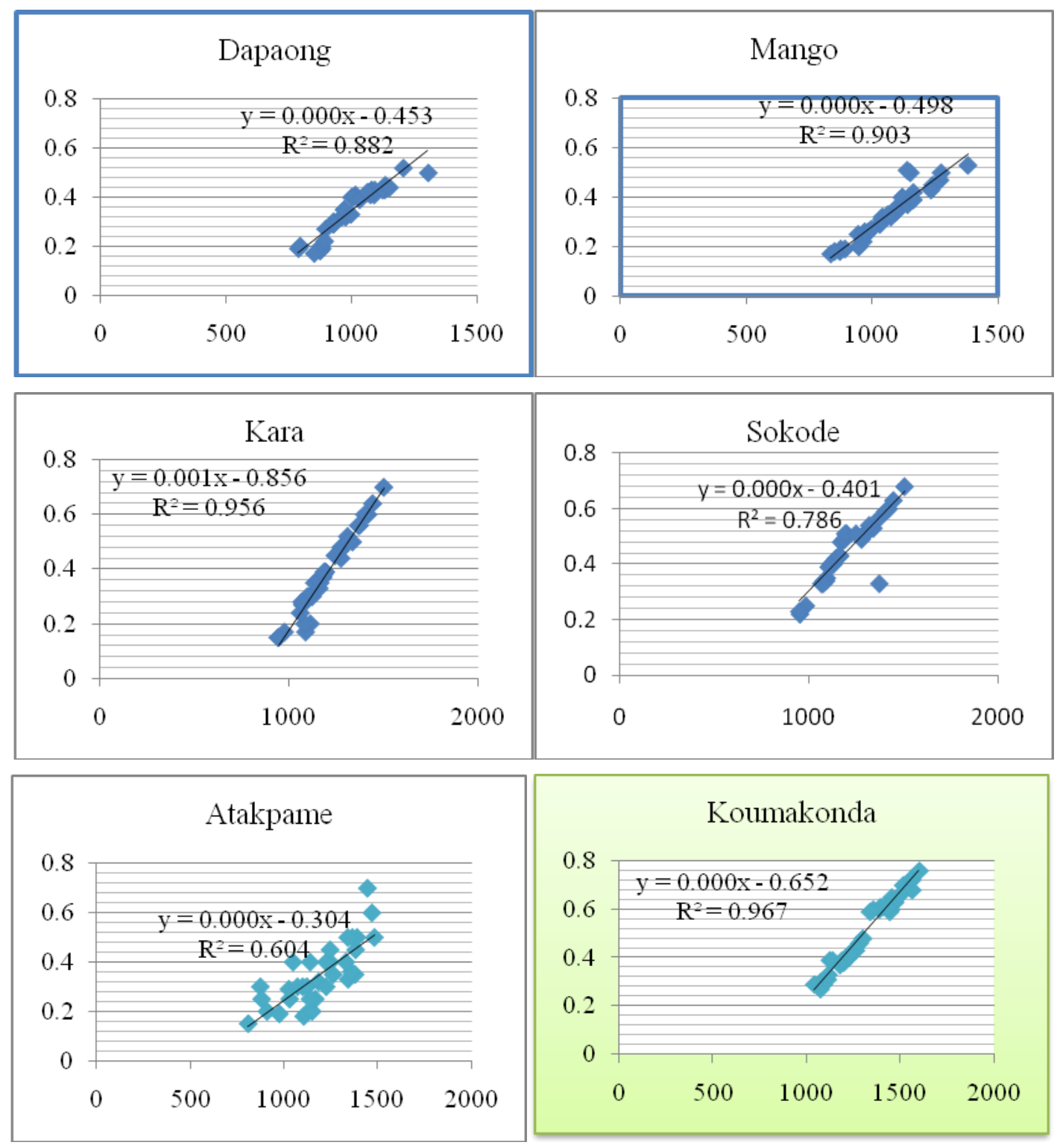


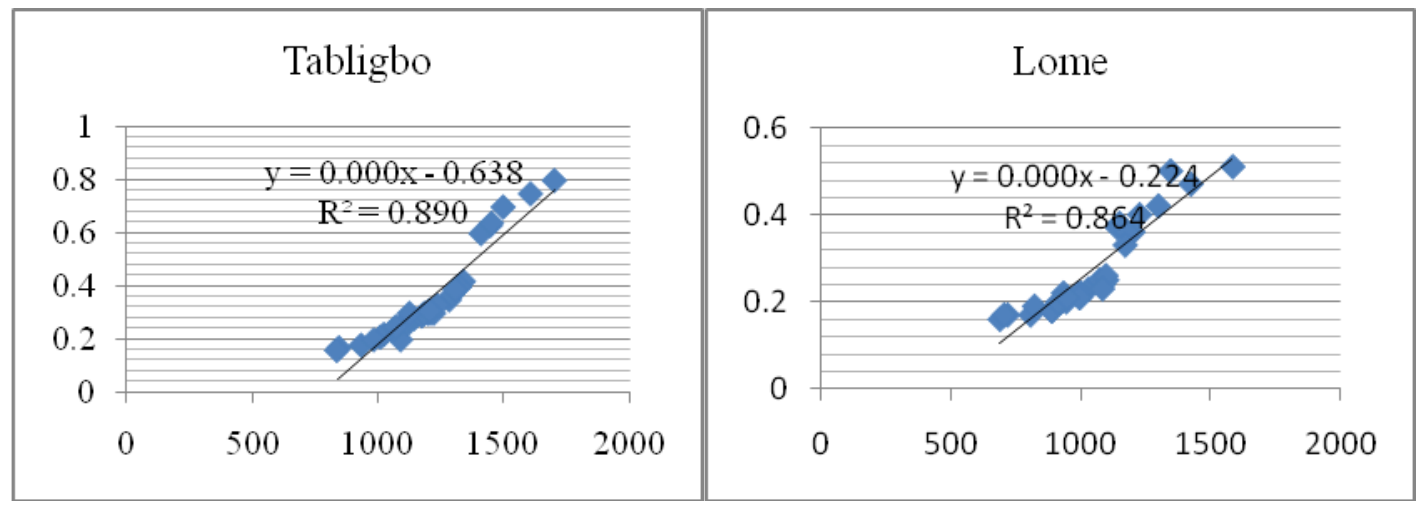

Figure 10. Annual changes in NDVI, rainfall $(\mathrm{mm})$ for the eight sampled meteorological stations in Togo during 1984-2017

Through the regressions analysis between temperature and NDVI in one hand and between NDVI and annual rainfall at local scale in the eight sampled meteorological stations areas, several observation can be seen from 1984 to 2017

\section{Under the Guinean subequatorial climate including Lome, Tabligbo, Kouma konda and Atakpame meteorological stations}

- At Lome area, the relationship between NDVI and rainfall was significant at $\mathrm{p}<0.05$. The Kendall coefficient between NDVI and rainfall was 0.912 with a Pearson coefficient of 0.92 (Table 1; Figs. 9 and 10).

- In the Tabligbo area, the correlation between NDVI and rainfall is significant at $\mathrm{p}<0.05$. The Kendall coefficient between NDVI and rainfall is 0.944 and the Pearson coefficient is also 0.94 (Figs. 9 and 10).

- For the Kouma konda area, the correlation between NDVI and rainfall is significant at $\mathrm{p}<0.05$. The Kendall coefficient between NDVI and rainfall is 0.92 while the Pearson coefficient is 0.98 (Fig. 9).

- For the Atakpame area, NDVI changes according to rainfall more than temperature (Figs. 9 and 10). The Kendal's coefficient is -0.104 between temperature and rainfall and 0.625 between NDVI and rainfall and 0.028 between temperature and NDVI.

- In the Sokode area, the relationship between NDVI and rainfall is significant at $p<0.05$. The Kendall coefficient between NDVI and precipitation is 0.845 while the Pearson coefficient is 0.88 (Table 1; Figs. 9 and 10).

\section{Under the Tropical Sudanese climate including Dapaong, Mango, Kara and Sokode meteorological stations}

- At Sokode station, NDVI was found to correlate strongly with NDVI with a pvalue less than 0.00001 and statistic $\mathrm{Z}$ equal to 4.26489. The Pearson coefficient and the Kendall's were 0.85 and 0.88 respectively. But the temperature did not correlate strongly with the NDVI with a p-value less than 0.05 . The correlation coefficient for temperature and NDVI were -0.101 for Kendall's and -0.05404108 for Pearson's. 
- For the Kara area, the only significant relationship was between NDVI and rainfall ( $\mathrm{p}<0.05)$. The Kendall coefficient between NDVI and rainfall is 0.913 while the Pearson coefficient is 0.97 (Figs. 9 and 10).

Table 1. Annual correlation coefficient and two-tailed significance test values ( $p$ ) between NDVI, rainfall, and temperature at local level during the last three decades (1984-2017) in the eight sampled areas in Togo

\begin{tabular}{c|c|c|c|c|c|c|c|c}
\hline \multicolumn{7}{c|}{ Annual rainfall/NDVI } & \multicolumn{4}{c}{ Annual temperature/NDVI } \\
\hline Station & p-value & $\mathbf{z}$ & MK & Pearson's & z & MK & Pearson's & p-value \\
\hline Lome & $<0.00001$ & 4.26489 & 0.92 & 0.9 & 0.35843 & -0.102 & -0.1621578 & 0.360009 \\
Tabligbo & $<0.00001$ & 4.26489 & 0.94 & 0.9 & 0.51924 & -0.011 & -0.0692178 & 0.698202 \\
Atakpame & $<0.00001$ & 4.26489 & 0.66 & 0.7 & 0.97054 & 0.028 & 0.03732365 & 0.834111 \\
Koumakongda & $<0.00001$ & 4.26489 & 0.92 & 0.9 & 0.17585 & 0.071 & 0.10106936 & 0.569794 \\
Sokode & $<0.00001$ & 4.26489 & 0.88 & 0.85 & 0.71162 & -0.101 & -0.0540411 & 0.76165 \\
Kara & $<0.00001$ & 4.26489 & 0.913 & 0.977 & 0.1516 & 0.34 & -0.1379442 & 0.439751 \\
Mango & $<0.00001$ & 4.26489 & 0.9 & 0.95 & 1.23214 & -0.004 & 0.02444853 & 0.891052 \\
Dapaong & $<0.00001$ & 4.26489 & 0.896 & 0.39 & 0.97054 & 0.027 & 0.03732365 & 0.834111 \\
\hline
\end{tabular}

In the Mango region, the only significant relationship also is that between NDVI and rainfall which is significant at $\mathrm{p}<0.05$. The Kendall coefficient between NDVI and rainfall is 0.92 while the Pearson coefficient is 0.98 (Fig. 9 and 10).

At Dapaong, the sole statistical relationship was between NDVI and rainfall, and was significant at $\mathrm{p}<0.05$. The Kendall coefficient between NDVI and rainfall is 0.896 while the Pearson coefficient is 0.94 (Fig. 9 and 10).

In addition, both at local and national scale the climatic parameters showed obvious changes for annual temperatures and annual rainfalls. At national level, the general trend of temperature is increasing since 1990. Before this upward trend, there has a slight decrease from 1984 to 1990 (Fig. 2). This observation is the same at local scale as the entire national trend of temperature (Fig. 4).

For the annual rainfall, the general trend at national level showed as constant trend $\left(\mathrm{y}=0.611 \mathrm{x}+176.8, \mathrm{R}^{2}=0.002\right)($ Fig. 2$)$ with slights changes. It decreases from 1948 to 2000 and increases from 2000 to 2010 before dropping till 2015 and started increasing from 2015 to 2017 . The general trend of rainfall is the same at national level for annual mean NDVI while at local level, NDVI showed different trends at each meteorological station areas.

In Dapaong, the general trend of NDVI is increasing (Dapaong annual rainfall $=0.001 \mathrm{x}-2.776 \mathrm{R}^{2}=0.024 ;$ Fig. 4) with maximum values in 1999 and 2007 and minimums in 1990, 1995 and 2014 mainly.

In the Mango area, NDVI increased from 1984-1990 and then decreased from 19902000 and then increased again from 2000-2010 before decreasing from 2010 to 2017 (Mango annual rainfall $=0.001 \mathrm{x}-2.456 \mathrm{R}^{2}=0.016 ;$ Fig. 4).

In the Kara area, the general trend of ndvi showed an increase (Kara annual ndvi mean $=0.004 \mathrm{x}-8.987, \mathrm{R}^{2}=0.098$ (Fig. 4). It peaked down in 1990, 2000, 2005 and 2015 mainly with maximums in 1989, 1995, 2003and 2010 mainly.

At Sokode, the NDVI showed a general upward trend during these last three decades from 1984 with a regression equation from Fig. 4 (Sokode annual NDVI $=0.002 \mathrm{x}-$ 
4.005, $\mathrm{R}^{2}=0.038$ ). Maximums were observed in the years 1989, 1995, 1997, 2003, 2008 and 2010 mainly.

At Atakpame, the general trend of NDVI is decreasing $y=-0.0001 x+1.493$, $\mathrm{R}^{2}=0.002$ ). At Kouma Konda, the NDVI trend is increasing slightly (Fig. 4) $\left(\mathrm{y}=0.000 \mathrm{x}-1.026, \mathrm{R}^{2}=0.002\right)$ with maximums in 1985, 1989, 1995, 2002 and 2008 mainly and minimums in 1986, 1990, 1992, 1996, 2000, 2004, 2012 and 2015 mainly.

At Tabligbo it can be seen that the general trend of NDVI is decreasing $(y=-0.002 x$ $+6.120)$.

Lome station showed that the uptrend years of the annual temperature were different from that of rainfall and NDVIPlots revealed hanges in average NDVI between the eight sampled meteorological stations and their surroundings for NDVI, temperature and rainfall from 1984 to 2017 in Togo for chlorophyllous vegetation (green plants) (Figs. 5-7). There was a remarkable increase in (year) at (area name). All annual uptrend of NDVI can be interpreted us a vegetation growing.

\section{Discussion}

\section{NDVI and climatic variability analysis at national level}

The inter-annual variation of temperature trend at the national level has been increasing since 1984 in Togo. This increase of temperature has been already found by some previous studies related to climate change (Badameli et al., 2015). At the same time, the general trend of annual evapotranspiration is being increasing, these two factors correlated strongly (Figs. 9-10).

In addition, NDVI, which reflects chlorophyll (green plant material), correlated remarkably with rainfall at national level. These two findings showed a couple of factors which correlate one another: (NDVI, rainfall), and (temperature, evapotranspiration) while an increase of annual rainfall decreases the evapotranspiration (Figs. 2-3). This last observation can be explained by the decrease of temperature by rainfall which caused the evapotranspiration to decrease.

In other studies, an obvious impact of climatic factors on annual NDVI trends was shown, and differences can exist among the chlorophyll of plant species responding to the climate changes (Gang et al., 2016).

\section{NDVI and climatic variability analysis at local level}

All of the eight selected meteorological stations showed that a correlation between rainfall and NDVI was significant (Figs. 9-10) with a p-value $<0.00001$. The correlation coefficients both of Pearson and Kendall are highly positive and near 1 with a statistic $\mathrm{Z}=4.26489$. Except for KARA area where both the coefficient of Kendall is high and above 0.3 (Fig. 10) between NDVI and temperature and above 0.8 between NDVI and rainfall (Fig. 10). Between temperature and NDVI, the correlation is not significant (Fig. 9-10). These findings implied that NDVI which reflects the vegetation activity becomes rainfall dependent in the research area. This statement confirms the fact that green plants depend on water for their photosynthesis activities as all these findings are consistent with some of the previous studies related to the topic of rainfall and NDVI correlation (Malo et al., 1990). In addition, the NDVI is known not only to correlate well with rainfall, and also can be used as a useful tool to monitor rainfall under different climatic conditions (Di et al., 1994). 
Other studies found that water availability is a limiting factor of green plant activity especially in carbon sequestration and photosynthesis activities (Gang et al., 2016). It has been found that, evapotranspiration can be used as a tool to measure the chlorophyll of green plants, with the capacity to influence rainfall, for instance, in the research area, the evapotranspiration correlates strongly with temperature (Fig. 3). An increase in temperature accelerates the evapotranspiration both by plants (transpiration) and rivers or soil (evaporation) explaining the positive correlation between annual mean temperature and evapotranspiration during these last three decades in Togo. These findings were consistent to the one found previously by (Shouichi et al., 1979) who reported that, between soil and vegetation there is the transfer of energy due to consumption of net radiation by green plants through photosynthesis, which will be used for evapotranspiration. Some other previous findings recognized the relationship between evapotranspiration and temperature due to solar radiation and chlorophyllous plant requirements for their several biosynthesis functions (Chapman et al., 1972; Julian et al., 1973; Wickham et al., 1978). In fact, not only the solar radiation (sunshine) but also temperature and rainfall (water availability) impacts deeply green plants photosynthetic activities under any climatic conditions (Gang et al., 2016).

This study showed that, the general trend of annual temperature is obviously increasing since 1990 in Togo. This upward trend could probably explained by global climate changes in the West Africa and the whole world. Many other studies confirmed this findings (IPCC, 2007) stressing the need to survey the influence of climatic factors especially temperature on vegetation.

Many other studies are of the opinion that the increase of annual temperature influences vegetation growth (Rustad, 2001). This statement is contrary to the observations made during our research in Togo where the upward trend of temperature does not correlate with the vegetation (NDVI) growth. Thus, the climatic factors are not the only factors to influence chlorophyllous plants growth.

\section{Socio-economic drivers of NDVI and climatic inter annual changes}

Any changes of NDVI reflects directly the variation of green plant covers, an indicator of chlorophyll or plants activity (photosynthesis and evapotranspiration) (Tucker et al., 1979). Therefore, the decrease of NDVI at national level from 1990 can be due to uncontrolled tree logging during the political events as bad implementation and understanding of democratization which put more pressure on the protected areas especially on forestland. From this year, the half part the Togolese national protected areas has been spoilt away putting the country on the list of highest rate of deforestation countries (Blaser J., 201) with a deforestation rate reported at $4.5 \%$ each year in 2000 (Fig. 4). Thus, the anthropogenic pressure on vegetation can be also justified by domestic energy needs as the population is increasing sharply, as their household energy use relies mainly on firewood and charcoal, and also for traditional medicinal use (Wala et al., 2005; Folega, 2011). Natural gas energy can be promoted and subsidized by the national leaders and reinforcements can be required in woodland, forest and natural protected areas management for more stringent restrictions for sustainability in nature conservation and green recovery.

In other perspectives, the high dependency of the majority of households on plant resources and farming related activities are also explained by the low income of the population in developing countries and the general conditions of poverty related resource use (Mukete, 2016). Therefore, the unceasing decrease of the forestlands in 
Togo is due to anthropogenic pressure, especially in rural areas to the detriment of the forest and green vegetation in Togo.

\section{Conclusions}

During these last three decades in Togo from 1984 to 2017, the annual temperature, rainfall, evapotranspiration and NVDI obviously changed. A correlation analysis based on the annual time series data of temperature, rainfall, NDVI and evapotranspiration showed that, (1) rainfall correlated strongly with NDVI which reflect the chlorophyllous plants activities both at local and national scale. (2) evapotranspiration was influenced by annual temperatures all over the country in the eight sampled meteorological stations while (3) evapotranspiration and rainfall correlated negatively. (4) annual NDVI changes can be used to monitor annual rainfalls. (5) anthropogenic activities such as deforestation by uncontrolled tree logging, farming and low household income were the main contributing factors in addition to climate change. Among the high deforestation countries in the world, the Togo a national leaders would mitigate this challenge by promoting alternative energy sources to replace firewood for households, especially natural gas and reinforcements to be implemented in the current resources managements plans by participative management for sustainable development in Togo. The national level of climatic variations measurements and their impacts on some main species in the study areas is encouraged in next research projects to clarify the specific influence of climate change on each plant species.

Acknowledgements. This research was funded by the International Science \& Technology cooperation Programme of China (2015DFR31130) and the National Natural Science Foundation of China (31670715; 41471029; 41371500). We are also grateful to the Chinese and Togolese Government for the cooperation scholarship and to my Supervisors and to Eve Bohnett for their generous help in the field investigation and English improvement during this research.

Conflict of interests. The authors declare that there is no conflict of interests regarding this paper.

\section{REFERENCES}

[1] Adjoussi, P. (2000): Changement climatique global: évaluation de l'évolution des paramètres climatiques au Togo. - Mémoire de maîtrise, Département de Géographie, Université de Lomé.

[2] Akpagana, K., Guelly, A. K. (1994): Nouvelles especes d'Angiospermes pour IA flore du Togo. - Acta Bot. Gallica 141(6/7): 781-787.

[3] Badameli, A., Bubreuil, V. V. (2010): Diagnostic of climatic changes in Togo through temperature evolution from 1961 to 2010. - XXVIIIe Colloque de l'Association Internationale de Climatologie, Liège 2015.

[4] Bartlett, D. S., Hardisky, M. A., Johnson, R. W., Gross, M. F., Klemas, V., Hartman, J. M. (1988): Continental scale variability in vegetation reflectance and its relationship to canopy morphology. - International Journal of Remote Sensing 9: 1223-1241.

[5] Biasutti, M., Sobel, A. (2009): Delayed Sahel rainfall and global seasonal cycle in a warmer climate. - Geophysical Research Letters 36(L23): 707.

[6] Blain, G. C. (2013): The modified Mann-Kendall test: on the performance of three variance correction approaches. - Bragantia, Campinas 72(4): 416-425. 
[7] Blaser, J., Sarre, A., Poore, D. et al. (2011): Status of Tropical Forest Management 2011. - ITTO Technical Series No 38. International Tropical Timber Organization, Yokohama, Japan. http://www.itto.int/news_releases/id=2663 (accessed on 28 February 2013).

[8] Brunei, J. F., Scholz, H., Hiepko, P. (1984): Flore analytique du Togo. Phanerogames. GTZ, Eschorn.

[9] Capodici, F. G., Ciraolo, G., Loggia, L., Liuzzo, L. V., Noto, M. T. (2008): Time Series Analysis of Climate and Vegetation Variables in the Oreto Watershed (Sicily, Italy). European Water 23/24: 133-145.

[10] Chapman, A. L., Kininmonth, W. R. (1972): Water balance model for rain-grown, lowland rice in northern Australia. - Agric. Meteorol. 10: 65-82.

[11] Chuai, X. W., Huang, X. J., Wang, W. J., Bao, G. (2013): NDVI, temperature and precipitation changes and their relationships with different vegetation types during 19982007 in Inner Mongolia, China. - International Journal of Climatology 33: 1696-1706.

[12] Cui, L. Shi, J. (2010): Temporal and spatial response of vegetation NDVI to temperature and precipitation in eastern China. - Journal of Geographical Sciences 20(2): 163-176.

[13] Di, L., Rundquist C., Luoheng, H. (1994): Modelling relationships between NDVI and precipitation during vegetative growth cycles. - International Journal of Remote Sensing 15(10): 2121-2136.

[14] Ern, H. (1979): Die Vegetation Togo. Gliederung, Gefährdung, Erhaltung. - Wildenowia 9(2): 295-312.

[15] FAO (2006, 2017): http://www.fao.org/home/fr/. - FAO, Rome.

[16] Folega, F., Zhang, C. Y., Samake, G., Wala, K., Batawila, K., Zhao, X. H., Akpagana, K. (2011): Evaluation of agroforestry species in potential fallows of areas gazetted as protected areas in north-Togo. - Afr J Agric Res 6(12): 2828-2834.

[17] Folega, F., Woegan, Y., Marra, D. (2015): Long term evaluation of green vegetation cover dynamic in the Atakora mountain chain (Togo) and it relation to carbon sequestration in West Africa. - Journal of Mountain Science 12(4):921-934

[18] Fontodji, K. J. (2007): Impact de la production du charbon de bois sur les propriétés du sol et la biodiversité au Togo. - Mémoire de DEA, Université de Lomé, Togo.

[19] Foody, G. M. (2003): Geographical weighting as a further refinement to regression modelling: an example focused on the NDVI-rainfall relationship. - Remote Sensing of Environment 88: 283-293.

[20] Fu, G., Li, S.W., Sun, W., Shen, Z. X. (2016): Relationships between vegetation carbon use efficiency and climatic factors on the Tibetan Plateau. - Canadian Journal of Remote Sensing. 42:16-26.

[21] Gausman, H. W. (1985): Plant Leaf Optical Properties in Visible and Near-Infrared Light. - Graduate Studies \#29, Texas Tech University, Lubbock, TX.

[22] Gazull, L. (2009): Bassin d'approvisionnement en bois-énergie de la ville de Bamako. Une approche par un modèle d'interaction spatiale. - Thèse de Doctorat, Université de Paris.

[23] Gilabert, M., Gonzalez-Piqueras, J., Garcia-Haro, F. J. (2002): A generalized soiladjusted vegetation index. - Remote Sensing of Environment 82: 303-310.

[24] Goward, S. N., Tucker, C. J., Dye, D. G. (1985): North American vegetation patterns observed with the NOAA-7 advanced very high resolution radiometer. - Veqetatio 64: 314.

[25] Helsel, D. R., Hirsch, R. M. (1992): Statistical Methods in Water Resources. - Elsevier, New York.

[26] Ichii, K. A., Kawabata, Y. (2002): Global correlation analysis for NDVI and climatic variables and NDVI trends: 1982-1990. - International Journal of Remote Sensing 23(18): 3873-3878.

[27] IPCC (2007): Climate Change 2007. The Physical Science Basis. - In: Solomon, S., Qin, D., Manning, M., Chen, Z., Marquis, M., Averyt, K. B., Tignor, M., Miller, H. L. (eds.) Contribution of Working Group I to the Fourth Assessment Report of the 
Intergovernmental Panel on Climate Change. Cambridge University Press Cambridge, UK and New York, USA.

[28] IPCC (2013): Climate Change 2013. The Physical Science Basis. - In: Plattner, G.-K., Tignor M., Allen S. K., Boschung J., Nauels A., Xia Y., Bex V., Midgley P. M. (eds.) Contribution of Working Group I to the Fifth Assessment Report of the Intergovernmental Panel on Climate Change. Cambridge University Press, Cambridge, UK, New York, USA.

[29] Julian, S. I. (1973): Water Management Innovations in the National Irrigation Administration. - In: Water Management in Philippine Irrigation Systems: Research and Operations. The International Rice Research Institute, Los Banos, Philippines, pp. 97112.

[30] Julien, M. (2014): Estimation de la biomasse de canne par modélisation et télédétection, Application à la Réunion. Océanographie. - Université de la Réunion, France.

[31] Kendall, M. G. (1975): Rank Correlation Methods. - Charles Griffin, London, UK.

[32] Kleinbaum, G., Kupper, L., Muller, K. (1998): Applied Regression Analysis and Other Multivariate Methods. - Duxbury Press, Toronto, pp.111-119.

[33] Kokou, K., Guy, C., Koffi, A. (1999): Analyse floristique des îlots forestiers du sud du Togo. - Acta Botanica Gallica 146(2): 139-144.

[34] Kokou, K., Nuto, K., Atsri, H. (2009): Impact of charcoal production on woody plant species in West Africa: a case study in Togo. - Scientific Research and Essay 4(8): 881893.

[35] Ma, M. G., Veroustraette, F. (2006): Interannual variability of vegetation cover in the Chinese Heihe River Basin and its relation to meteorological parameters. - International Journal of Remote Sensing 27: 3473-3486.

[36] Malo, A. R., Nicholson, S. E. (1990): A study of rainfall and vegetation dynamics in the African Sahel using normalized differenced vegetation index. - Journal of Arid Environments 19: 1-24.

[37] Mann, H. B. (1945): Nonparametric tests against trend. - Econometrica 13(3): 245-259.

[38] Martiny, N., Camberlin, P., Richard, Y., Phillippon, N. (2006): Compared regimes of NDVI and rainfall in semi-arid regions of Africa. - International Journal of Remote Sensing 27(23-24): 5201-5223.

[39] Mbatu, R. (2006): Forest policy, forest loss and land use cover change in Cameroon. $\mathrm{PhD}$ Thesis, Oklahoma State University, Stillwater, USA.

[40] Meng, M., Ni, J, Zong, M. J. (2011): Impacts of changes in climate variability on regional vegetation in China: NDVI-based analysis from 1982 to 2000. - Ecological Research 26: 421-428.

[41] Mukete, B., Sun, Y., Zama, E., Achem, B., Mukete, T., Ndolo, L., Lonje, B. (2016): Environmental degradation in conflict and post-conflict regions. - International Journal of Environmental Protection and Policy 4(6): 187-195.

[42] Mukete, B., Sun, Y., Etongo, D., Sajjad, S., Abdul, M. (2018): Assessing the drivers of land use change in the Rumpi hills forest protected area, Cameroon. - Journal of Sustainable Forestry. 37:592-618.

[43] Nicholson, S. E., Farrar, T. J. (1994): The influence of soil type on the relationships between NDVI, rainfall and soil moisture in semiarid Botswana. I. NDVI response to rainfall. - Remote Sensing of Environment 50: 107-120.

[44] Prince, S. D. (1991): Satellite remote sensing of primary production: comparison of results for Sahelian grassland 1981-1998. - International Journal of Remote Sensing 12: 1301-1311.

[45] Richard, Y., Poccard, I. (1998): A statistical study of NDVI sensitivity to seasonal and interannual rainfall variations in Southern Africa. - International Journal of Remote Sensing 19(15): 2907-2920. 
[46] Rosental, W. D., Blanchard, B. J., Blanchard, A. J. (1985): Visible infrared microwave agriculture classification, biomass, and plant height algorithms. - IEEE Transactions on Geoscience and Remote Sensing (2):84-90.

[47] Rouse, J. W., Hass, R. H., Schell, J. A., Deering, D. W., Harlan, J. C. (1974): Monitoring the Vernal Advancement and Retro Gradation (green wave effect) of Natural Vegetation. - NASA/GSFC Type 111 Final Report, Greenbelt, MD.

[48] Rustad, L. E., Campbell, J. L., Marion, G. M., Norby, R. J., Mitchell, M. J., Hartley, A. E., Cornelissen, J. H. C., Gurevitch, J., GCTE News (2001): A meta-analysis of the response of soil respiration, net nitrogen mineralization, and aboveground plant growth to experimental ecosystem warming. - Oecologia 126(4): 543-562.

[49] Schultz, P. A., Halpert, M. S. (1995): Global analysis of the relationships among a vegetation index, precipitation, and land surface temperature. - International Journal of Remote Sensing 16: 2755-2777.

[50] Sellers, P. J. (1985): Canopy reflectance, photosynthesis, and transpiration. - Int J Remote Sens 6: 1335-1372.

[51] Serreze, M. C., Walsh, J. E., Chapin III, F. S., Osterkamp T., Dyurgerov M., Romanovsky V., Oechel W. C., Morison J., Zhang T., Barry R. G. (2000): Observational evidence of recent change in the northern high-latitude environment. - Climatic Change 46: 159-207.

[52] Shouichi, Y. (1979): A simple evapotranspiration model of a paddy field in tropical Asia. - Soil Science and Plant Nutrition 25(1): 81-91.

[53] Tao, S., Dawson, R. W. (2002): Relations between AVHRR NDVI and eco-climatic parameters in China. - International Journal of Remote Sensing 23: 989-999.

[54] Tarpley, J. D., Schneider, S. R., Money, R. L. (1984): Global vegetation indices from the NOAA-7 meteorological satellite. - Journal of Climate and Applied Meteorology 23: 491-494.

[55] Townshend, J. R. G., Gofff, T. E., Tucker, C. J. (1985): Multi-temporal dimensionality of images of normalized difference vegetation index at continental scales. - IEEE Transactions on Geoscience and Remote Sensing 23: 888-895.

[56] Traore, S. A., Madsen. S. (1998): Quelques caractéristiques de la régénération naturelle des espèces ligneuses du Parc National du Niokolo Koba (Sénégal oriental). Végétation et biodiversité au Sahel. - AAU Report 39: 275-288.

[57] Tucker, C. J. (1979): Red and photographic infrared linear combinations for monitoring vegetation. - Remote Sens Environ 8: 127-150.

[58] Wala, K., Sinsin, B., Guely, A. K., Kokou, K., Akpagana, K. (2005): Typology and structure of parkland in the prefecture of Doufelgou (Togo). - Sécheresse 16(3): 209-216.

[59] Wang, J., Price, K. P., Rich, P. M. (2001): Spatial patterns of NDVI in response to precipitation and temperature in the central Great Plains. - International Journal of Remote Sensing 22(18): 3827-3844.

[60] Wang, S. P., Duan, J. C., Xu, G. P., Wang, Y. F., Zhang, Z. H., Rui, Y. C., Luo, C. Y., Xu, B., Zhu, X. X., Chang, X. F., Cui, X. Y., Niu, H. S., Zhao, X. Q., Wang, W. Y. (2012): Effects of warming and grazing on soil $\mathrm{N}$ availability, species composition, and ANPP in an alpine meadow. - Ecology 93(11): 2365-2376.

[61] Weiss, J. L., Gutzler, D. S., Coonrod, J., Dahm, C. N. (2004): Seasonal and inter-annual relationships between vegetation and climate in central New Mexico, USA. - Journal of Arid Environments 57(4): 507-534.

[62] Wickham, T. H., Sen, L. N. (1978): Water Management for Lowland Rice: Water Requirements and Yield Response. - In: Soils and Rice. International Rice Research Institute, Los Banos, Philippines.

[63] Wilson, E. F., Sader, S. A. (2002): Detection of forest type using multiple dates of Landsat TM imagery. - Remote Sens Environ 80: 385-396. 
[64] Zhang, G. L., Xu, X. L., Zhou, C. P., Zhang, H. B., Ouyang, H. (2011): Responses of grassland vegetation to climatic variations on different temporal scales in Hulun Buir Grassland in the past 30 years. - Journal of Geographical Sciences 21(4): 634-650. 